\title{
Bring Your Friends to the Zoo
}

\section{Frederick Busch}

Because many of them did not know when or how to say "no" and ate too much and the wrong kind of food-sometimes fatally. They spent the day begging and lost health, too, through lack of exercise. The NO FEEDING RULE has enabled us to establish balanced diets for them, preserve their health and encourage breeding. In one year, while visitors were offering food, the elephants seized no less than fourteen coats, twelve handbags, ten cameras, eight gloves and six return tickets to Leicester, damaging them beyond repair. In the same year one hundred eighty visitors were bitten by other animals-monkeys, parrots, cockatoos and ponies. We want it to be a happy day for you and all the animals.

Present yourself at nine-thirty in the morning as the cashier slides his window up. It is advised that when you ask for two tickets, at eight shillings apiece, you calculate that there are twenty shillings in a pound and you are asking him to change a ten-pound note before he's done any business. Check your fly and clear your throat and look at all the bus stops while he turns his head away and then, because it is an English zoo, offers you apologies, and then commits revenge, smiling: nine pounds four in coin-half-pound pieces, two-shilling pieces, one-shilling pieces, a clanking lump in your sportcoat pocket. You should at this point sound like a sack of chains. Watch the bus stops.

Take twenty-four thousand customers on an average summer's day-and one in four brought food for the animals. Six thousand paper bags of food was a very large "extra," seven days a week! We want it to be a happy day for you and all the animals. Please Do Not Feed Them, for we want it to be a happy day for you and all the animals. Please.

Then close the guide and say "Good morning. Hi."

At this time of year she wears a light tan raincoat that is stiff and clean. Her Liberty's scarf, a bright blue paisley, shows at the throat. Her hem is too long for fashion and her slender legs are not shown to her best advantage. Her hair blows in the harsh autumn wind that has risen in August, a warning of what the year is to be, but her hair is heavy and it settles about her as the wind wavers, and 
she still looks composed. She wears her hair simply and does not look stylish; she looks as if she cares to look no other way, and so she carries an air of threat: she is too much her own construction, insufficiently swayed by London modes, or winds of summer, you. Greet her by saying "Good morning. Hi."

Once through the gate, face right. The Deer House, The Camel House, The Giraffe House, The Cattle and Zebra House and The Antelope House will all be found on your left across a canal and a wild ravine. Water Bus rides on the artificial river start at ten. As you face your right you see a path before you. Take it. You pass, on your right, The Owls Aviary and The Pheasantry. All of the pheasants have gone away and you can count up fourteen empty cages, waiting. You can listen to the wind across The Reptile House, The Reptiliary, The Gentlemen's Toilets, The Charles Clore Pavilion for Mammals and Moonlight World. Ahead of you a great fence of wide-mesh wire catches the wind; it is a huge crazy sail that is warped to the ground like a tent and has a door of brushed aluminum. It peaks in twenty places, it bulges at its sides; thick steel pipes at strange angles jut like spars and when you walk inside, saying, "You go first. You come first, you always came first for me. You know that," the noise that she makes for you by listening in silence, saying nothing, even when you try to smirk your sudden words away, is lost. For you are in The Snowdon Aviary, opened in 1965, the first out-of-doors walk-through aviary in The London Zoo, which houses many birds from a variety of natural habitats. The Aviary was designed by Lord Snowdon in association with Mr. Cedric Price and Mr. Frank Newby. A special leaflet about The Aviary is available from The Zoo Shop (price 1/-). Lost, because the wind is constantly a high sighing human voice inside this cage. The ground slopes sharply and the steep bank is cut by a narrow concrete walk. A wide-barred railing keeps you from falling down, as the waterfall goes down, roaring, onto rocks and wet bright vegetation, but you must be cautious at the dangerous rail not to drop like the water down on the rocks and tangled bushes below, very far. There are trees and creepers, everything is twined and seizing and moist and you must take care in the constant wind in which the bellow of her silence is lost.

Shapes and colors move in the transplanted brush, something always is moving off the edge of your vision near a pool or in the shadow of a twisted tree or under something green. Over one hundred forty birds of every color are housed here, and below there are egrets ignoring you, herons and spoonbills; teal and ibises, touracos, kestrel, all were here this morning, will remain tonight, in the breathing wind and faintest rattle, as if chains were shaken, that the fence must always make.

Plans to make The London Zoo the most beautiful and modern Zoo in the world have been moving forward. Moving forward, out the final door, leaving you in The Aviary, she will face a wooden wall and large white sign: UNDER REDEVELOPMENT. Beyond and left she should see The West Bridge. Call her and the wind will crush your words. No birds will rise in fright at the sound of your voice. Move along the rail at which you must take care and leave this unique and justly famous structure. 
Say to her, waiting at The Regent's Canal before the bridge, "Did you want to leave me there with the other funny birds?"

"No. No. You aren't a funny bird."

"I thought maybe that's why you weren't talking to me."

"I am talking to you."

"Right, yes, you are talking to me. Right. What are you saying?"

"Nothing, I suppose. I don't know. Am I being cruel?"

"What's your best guess?"

"I'm not here to be cruel. I don't want anything bad to happen to you."

"Me neither."

"That's not why I'm here."

"I wonder if I could ask you why you are."

"Why I am?"

"Not in general, I mean. We could work out all the metaphysics later, how come you exist, et cetera. I mean why did-no. Dammit. You see? I'm a vicious man. I didn't come here, I didn't ask you to come here, so I could be nasty. Honest."

"No. I know."

"Now I don't."

"What?"

"I swear I all of a sudden have no idea why we're doing this. I think I would have stood in front of the gate on Prince Albert Road all day, waiting. I would have called your mother's house, I would have gone there and lied my way in. I mean it was crucial, understand? It was essential. Absolutely necessary to see you. Except I don't know why now. Why did you come?"

"Because you cabled me. It was very dramatic. You asked me to."

"But why did you want me to come?"

"Because you wanted me to. Stupid. Because in America-"

"Please: what happened in America? What did we do? What was it?"

"Oh that's an easy one. It was a scandal at your university. It was a humiliation to my husband. His students talked about it, your students talked about it. I shouldn't be surprised if you and I didn't manage to talk about it publicly every chance we'd had. Do you remember that oaf of a gibbering something-in-administration of yours, the one with the yellow plastic teeth? Ah, the benefits of exchange professorships, he said. Hands and everything else across the waters. What a pig he was."

"So is that what it was? An embarrassment?"

"You never should whine. I wish you wouldn't."

"But I need to know this!"

"You're spoiling your leave what-you-may-call-it."

"Leave of absence. I'm not on leave."

"Why are you in England, then? Your cable said sudden leave or something."

"Guess why I'm here. And I left very suddenly."

"Oh not me. You didn't come all the way over on account of me, that's hideous!” 
“Alright."

"You didn't."

"Alright."

"Yes you did."

"I don't want to discuss the mechanics of it."

"But all those miles!"

"Why did you fly over all those miles in the first place?"

"But it was end of term. The job was over, we had to come home."

"He had to come home."

"This an ancient conversation. Haven't we had it before? Often?"

"And how come you live at your mother's house?"

"Yes. How did you know that?"

"I called your husband on the phone."

"You rang my husband? You made my husband talk to you?"

"I'm sorry. You want me to be sorry?"

"I want you to feel like the through-and-through beast that you are."

You should not miss The Crane and Goose Paddocks. Cranes fly with outstretched neck and legs trailing behind them. They feed on seeds and small animal life, and nest on the ground.

To mention only a few of the fascinating exhibits, there are the stick insects which are masters of protective camouflage. The praying mantis, which preys on other insects, stalking them and finally pouncing upon them with its powerful, sharply spined, grasping forelegs, is a fascinating, sinister exhibit. Many of them have been reared in The Zoo from eggs sent in masses from warmer lands.

The bactrian camel has two humps. The dromedary has one hump.

While a sparrow has fourteen joints to its neck a giraffe has only seven. Giraffes rarely utter any sound.

Keep to the left on entering The Reptile House; it will help you to make the most of these notes. They store their poison in glands in their head. When they bite. The cobra's hood is produced by the spreading of certain ribs near the neck. Rattlesnakes warn by. Green mamba. Kirtland's tree snake looks like the bark of a tree. Then outside to The Broad Walk, directly ahead. Few people realize there are so many kinds of monkeys and apes. And The Charles Clore Pavilion for Mammals, opened in May of 1967.

Stand facing the door while she looks through its glass at the glass-faced cages where one can ascertain the waking/sleeping rhythms, burrowing habits and jumping capacities of small mammals on display, each in its natural habitat. When she turns from the binturongs and tree kangaroos, by glass twice removed, and the sound of your wordless shout rains onto visitors and the brownish cement of the building, The Otter Pool to your right, The Staff Car Park to your left, The Outer Circle Walk will be at your back. Say "Why don't you live with your husband now? Why didn't you tell me when you left him? Why don't you let me love you?" Noting the stiffness of her stance, the sense she gives, like a smell of imminent flight in wild things, ask her lower, say more secretly, "Why?"

"My husband hates me." 
"Did he hit you?"

"Hate. Not hit. He doesn't hit."

"Do you hate me?"

"No. I don't know. No."

"I guess I ruined your life."

"Perhaps you did. And if you did you've no need really to be proud. That's simple enough to do. What could be more fragile?"

"Did you love me in America?"

"Please stop asking me questions like that."

"But you don't love me now."

"Now it doesn't matter if I do."

"Oh yes it does."

"I'm sorry. I mean now it makes no difference. No, not that either. I can't really say things cleverly, can I?"

"You can say. You do fine."

"I'm not trying to injure you, you see. I'm trying not to injure you. I'm tryinglisten to me as if I were a student. A stupid student. A stupid child. Which I am."

"Would you understand what I meant if I started to cry now?"

"Oh American men don't cry, though, do they? Please?"

"Of course not. You know how I keep forgetting things. Forgive me."

"You me."

"Well talk, talk, tell me. Tell me."

"Have you ever read the personals page of The Times? Our Times, over here?"

"Sherlock Holmes called that page the agony columns."

"Yes. There's a section headed In Memoriam."

"Yes."

"And on the anniversary of someone's death-this always comes directly after Marriages, you know."

“Doesn't it."

"On the anniversary of death the family place a message. Usually it's one sentence, headed with the dead person's last name in very dark letters. Sort of Smith, W. A.-To the loving memory of William Albert Smith, felled whilst on duty in Bosnia, August 11, 1913, perishing bravely at his Embassy post, ever remembered by all, sacred to the memory of his loving family. That sort of thing. I suppose people do read them. I sometimes read them when I've nothing better to do."

"You've recently been having nothing better to do."

"I've spent some time alone."

"I guess you have."

"Most often I feel spooky, sort of, you know, peeping. Looking at that sorrow or make-believe sorrow, all of it out on display, like a show or something. Of course it might be real agony, sometimes I think so. And how ghoulish it is of me to finger it and then go away. It's so morbid of me, isn't it? But I do it sometimes." 
"And you saw this ad put in by your husband, announcing his death and how he mourned it."

"No."

"I apologize for saying that."

"We both used to say things like that."

"Mostly me, I had less to lose. I used to think like that."

"What I want to tell you is during the time-I mean when my husband threw me out, as soon as we were home, really, and I lived in a room at my mother's. My old room. Lord. Why do you think things always work out like that?"

"You can come and live in my room."

"Anyway I read a lot of In Memoriams. I suppose I was thinking of writing my own. But do you know, the history of England is there, in those little drizzly horrible squibs of formal language. Things that happened before I was born, or when I was too young to remember. To the memory of so-and-so, he was shot down thus-and-such, France, 1942. Killed at sea, 1918. On and on. All those people dead, all those people remembering them. And then the little non-historical people. Killed in a tragic accident. Felled by a premature stroke. Dead before her tenth year. So much! And all those people remembering. Everything is gone, but they keep on remembering. The history is still left. The families are still left. Something is left. Death didn't kill it all, there is such sadness left. Like bones in a body when the skin is corrupted and gone all to powders. There is something left of what there was and the sad people keep it here."

"I'm trying to marry a widow, you mean?"

"I suppose. I'm so-"

"Well widows don't mourn at the zoo. They don't stay faithful to some kind of memories-after being unfaithful-by coming to meet their memories' cuckold that they're supposed to be faithful to after dishonoring what they're honoring now."

"I don't-I'm sorry, really, I really didn't get that. I don't understand what you said. Would you say it again?"

"No. I can't even remember it."

The Pavilion, designed to house The Zoological Society's large collection of small mammals, is a new building with one hundred cages and three outside enclosures, accommodating some two hundred burrowing, jumping, running and climbing animals-marmots, martens, civets, mongooses, lemurs, marmosets, squirrel monkeys, ocelots, wallabies, wombats, porcupines and acouchies. When you follow her inside you can skirt the upper-floor exhibits and walk directly to the stairs that go down. Observe the sign that says DO NOT SPEAK LOUDLY and BEWARE PICKPOCKETS. Put your hand on your wallet, check your fly, walk downstairs with your change adrift in your pocket, rattling.

You will see that this hot wandering chamber is dark, lighted only by tiny red bulbs. A rail divides each crypt of the chamber in half, and each wall is windowed. Several different worlds have been placed side-by-side, sealed off from one another and discrete, in each glass wall. Follow the wall, keep to the left of the rail. Such creatures as bats, kinkajous, flying squirrels, douroucoulis and bush- 
babies are normally active from dusk to dawn. In this large nocturnal section, known as The Moonlight World, special lighting has been installed, based on a study of these creatures' individual habits. This reverses their days and nights so that they are most active during public visiting hours. When the visitors leave, the lighting gradually increases and the animals fall asleep. They read The Times before retiring, and the angwantibos sing at the mouth of the gerbils' burrow as the lightbulbs buzz. Visacha. Mouse lemurs. Seldom seen in movement, seldom seen. For safety a dimly-lit green sign on the ceiling warns the visitors to STAND IN PLACE UNTIL YOUR EYES ARE USED TO THE DARK.

Call to her that your eyes are not used to the dark yet.

"Hush, will you? Listen, I have to go now."

She will have moved around several bends of the chamber by now, for her eyes have grown used to the dark. Call to her again. If she silences you, remain silent, for rare Allen's bushbabies live here and we want it to be a happy day for you and all the animals.

Still, you should call once more. Note that on the walls around you there are eyes, open eyes, blinking eyes, eyes that flee and return. Note that as you shout, as your feet shuffle, clanking the chains in your pocket, as your hands are held before you while you lurch, always to the left of your rail in The Moonlight World, how you frighten the eyes. They retreat. But they come back. The eyes in silence are the animals awake. When the visitors leave, the lighting gradually increases and the animals fall asleep. This reverses their days and their nights.

Now it is day. This is night to them, they are awake. As long as it is dark they are awake, for their eyes have grown used to the dark. And somewhere in the turnings of The Moonlight World she should say, "We have to go. I have to go."

"I don't want to go unless you come with me."

"No."

"Please."

"No. Hush."

"What about my history? Whose memory is that supposed to be sacred to? Who's remembering me? What about me? What good does loving you do me?"

But there is so much to see at London Zoo. Take twenty-four thousand visitors on an average summer's day. As they enter The Moonlight World they obey the sign that tells them to STAND IN PLACE UNTIL YOUR EYES ARE USED TO THE DARK. When you flee them as they enter you should keep to the left of the rail. The tiny animal eyes are open, of course, as you shuffle, jangling, for the eyes have grown used to the dark. This nighttime is their day. Take twentyfour thousand visitors. Come again and bring your friends to The Zoo. Beware pickpockets. Flee. Climb the stairs slowly and try to find her waiting for you at the top. When the visitors leave it is raw golden daylight. Come up blinking, blind. 